\title{
Impact of regulations on innovation in the field of medical devices
}

\author{
Rosa Mayelin Guerra-Bretaña ${ }^{1 *}$, Andrea Lucía Flórez-Rendón ${ }^{2}$ \\ ${ }^{1}$ Biomaterials Center, University of Havana, La Habana, Cuba. \\ ${ }^{2}$ Metropolitan Technological Institute, Medellín, Antioquía, Colombia.
}

\begin{abstract}
Introduction: The regulatory framework and standardized assay methods for classical biomaterials and implantable devices are harmonized at the international level, based on the risk assessment. However, innovative products need the development of more appropriate assay methods and streamline regulatory and scientific evaluation to encourage innovation and ensure more expedite delivery of novel, safe and effective innovative medical devices to patients. The aim of this work is to review the latest focus on the conflicting issues that are involved in the evaluation of recently developed biomaterials and medical devices. Methods: This paper is based on a review of the relevant academic literature regarding the field of medical devices over the last ten years (2008-2017). A systematic search was conducted in Medline data base for articles using "medical devices" + "regulations" + "innovation" in the title or abstract. Discussion: There is the widespread perception that research and marketing of innovative medical devices are moving swifter, even more so than the issues concerning evaluation methods and regulations. Collaboration among all the stakeholders could contribute to overcome the existing problems in medical device innovation.
\end{abstract}

Keywords Medical devices, Regulations, Innovation.

\section{Introduction}

Medical devices provide great benefits to the patients, although they also present potential risks, especially those devices intended to be used as implantable. The mission of the national regulatory agencies for medical devices is to protect patients and the whole society from unsafe products, in balance with the speed needed for the introduction in the market of innovative products which can be beneficial to patients, those promoting public health (Curfman and Redberg, 2011; Krouse, 2015; Krucoff et al., 2012; Stern, 2017).

Nowadays, the regulatory framework and standardized assay methods for medical devices, including biomaterials, are harmonized at the international level based on the risk assessment (Amato and Ezzell, 2014; Ho et al., 2016; Pane et al., 2017; Williams, 2015). In this general context, new implantable biomaterials have to pass

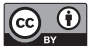

This is an Open Access article distributed under the terms of the Creative Commons Attribution License, which permits unrestricted use, distribution, and reproduction in any medium, provided the original work is properly cited.

How to cite this article: Guerra-Bretaña RM, Flórez-Rendón AL. Impact of regulations on innovation in the field of medical devices. Res Biomed Eng. 2018; 34(4):356-367. DOI: 10.1590/24464740.180054

*Corresponding autor: Centro de Biomateriales, Universidad de La Habana, Ave. Universidad e/ Ronda y G, La Habana CP 10400, Cuba. E-mail: mayelin@biomat.uh.cu

Received: 13 July 2018 / Accepted: 01 November 2018 through a series of regulatory assays in order to receive the approval for marketing. The necessary tests involve physical and chemical characterizations, biological in vitro and in vivo tests and finally clinical investigations. This pathway is well established for classical biomaterials and implantable devices. Nevertheless, emerging innovative products, such as nanobiomaterials, materials for tissue engineering and 3D-bioprinting tissues and organs face up some regulatory uncertainties that constitute barriers for their expedite delivery to patients.

The aim of this work is to review the latest works (2008-2017) focused on the conflicting issues that are involved in the evaluation of recently developed biomaterials and medical devices. Firstly, the background about the regulatory procedures in United States and the European Union is provided, and the specification of the medical innovation in the medical device sector is reviewed. On this basis, the relationships between medical device regulations and innovation are analyzed. Finally, cases of innovative medical technologies are analyzed.

\section{Methods}

This paper is based on a review of the relevant academic literature regarding the field of medical devices over the last ten years (2008-2017). A systematic search was conducted in Medline data base for articles using "medical devices" + "regulations" + "innovation" in their titles or abstracts. This initial search yielded 331 titles, 
which were checked to exclude those papers where authors use the searched keywords, without specifically focusing on the studied issue. After this first screening 160 articles remained, and the abstracts were analyzed to confirm which papers were interesting for this study. This final screening resulted in a list of 116 papers for content analysis (Figure 1).

Although all papers reviewed are linked to the relationships between medical device innovation and regulations, they were classified according to its main purpose into three categories (Figure 1). Category I (56.9\% of papers) includes those papers focused on regulatory issues and related to legal and/or ethical aspects, as well as international harmonization efforts, the regulatory role of clinical trials and case studies. Fourteen papers, focused mainly on the health technology assessment, are grouped in Category II (12.1\%). Category III gathers 36 papers $(31.0 \%)$ that analyze the innovation process, including financing, patenting, and clinical evaluation issues, the relationships between the key stakeholders that participate in the innovation and cases of medical device innovation.

The review was expanded with Google search using the same key-words, adding 54 documents. This open search allowed the revision of other original scientific papers and reports from different regulatory agencies, consulting and experts groups and governmental departments related to the articles analyzed in the systematic search. These documents are also important because the ethical, scientific and legal aspects of innovation in medical devices are of concern to multiple stakeholders and for this reason these topics are discussed in a variety of sources. However, due to considerations about the length of the paper, not all the papers reviewed in our study are cited.

\section{Background on Medical Devices Regulations}

National regulations agencies are critical to the innovation and competitiveness in the medical device sector. These agencies are the gatekeepers (Figure 2) who decide which products are effective and safe enough to enter the market (Curfman and Redberg, 2011; Gollaher and Goodall, 2011; Howard, 2016; Krucoff et al., 2012).

The first regulation for devices intended for human use was developed by the Device Amendments of 1976 of the Food and Drug Administration (FDA) of the United States (Center for Devices and Radiological Health, 2011; Lind, 2017; Van Norman, 2016; Wizemann, 2010) and until the late 1990s the FDA held a remarkable position among national regulatory agencies all around the world. Nowadays, the Center for Devices and Radiological Health (CDRH) is responsible for the premarket approval of medical devices in the United States and for the post-market surveillance of these products (Center for Devices and Radiological Health, 2011).

The FDA evaluation process for medical devices depends on the complexity and degree of risk to patients, following the risk classification of the product into three Classes. The processes are:

- Premarket notification also called 510(k) "clearance" for devices in Classes I (low risk) and II (moderate risk), based on manufacturing standards and clinical trials (optional). Compliance with the Quality System Regulation 21 CFR part 820 is a baseline requirement for medical device manufacturing firms.

Most Class I medical devices must be registered with FDA but are not required to undergo a premarket

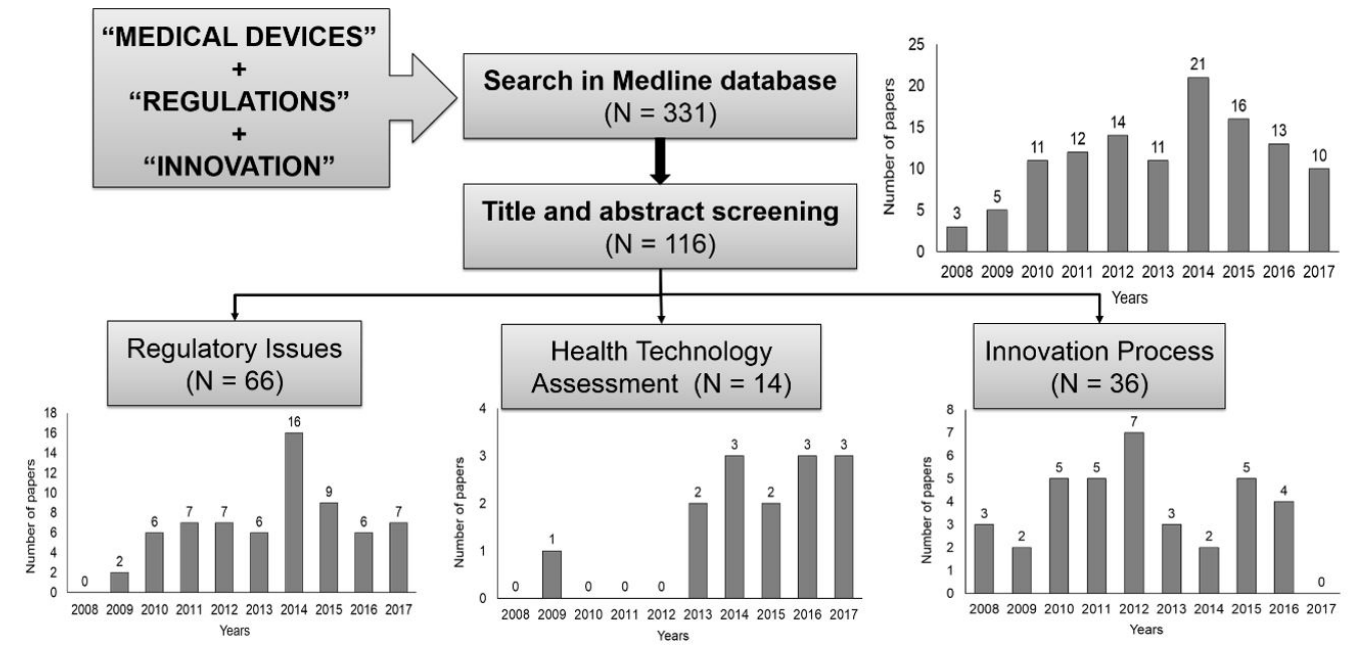

Figure 1. Medline review selection and classification process (flowchart) and appearance frequencies per year (bar charts). 


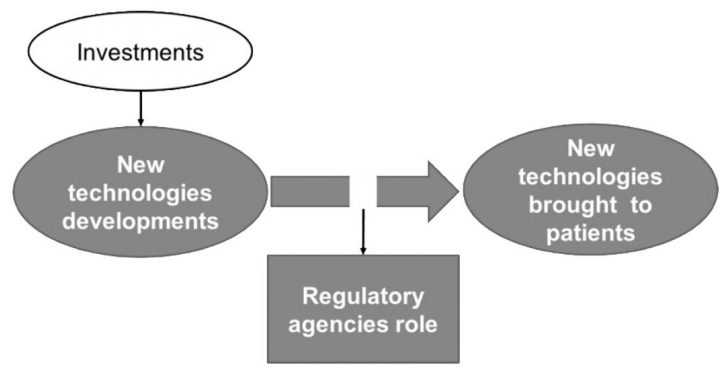

Figure 2. Participation of the regulatory agencies in the innovation process in the medical devices industry.

review $510(\mathrm{k})$, although they have to accomplish with the general controls, such as the manufacturer registration and notification to the FDA before marketing, good manufacturing practices (GMP), appropriate branding and labeling and general post market reporting procedures. Class II medical devices must involve special labeling requirements to accomplish mandatory standards and post market surveillance.

Low or medium risk devices are cleared for market if there are consistent evidences that they are similar to other devices already on the market ("Substantial Equivalence") or may require a "De Novo" review for devices for which there is no predicate. The "De Novo" process is applicable when the risks of a device are well-known and appropriate controls can be established to mitigate those risks.

- Premarket Approval (PMA) evaluation for Class III devices (high risk), is based on scientific reviews, clinical trials and manufacturing standards in addition to the general controls mentioned above. These devices could present serious risk to patients and thus require extensive testing.

FDA requires that "high-risk" devices demonstrate safety and effectiveness through clinical trials, conducted in accordance with Good Clinical Practices (GCP), which can be expensive and take years to be completed. For clinical approval, the devices follow investigational device exemption (IDE) approval by FDA. A device which has not been on the market is presumed to be a Class III unless its "substantially equivalency" to a legally marketed Class I or Class II device is demonstrated.

After the formation of the European Union (EU) the medical devices regulations of the state members were consolidated in a unified regulatory regime, eliminating the regulatory barriers for medical devices market inside the EU. This regulation system is based on three core principles: consistency, transparency and timeliness (Van Drongelen et al., 2015). Initially, the regulation system in the medical device sector in Europe was supported by three main documents:
- Directive 90/385, concerned with active implants (European Union, 1990);

- Directive 93/42, which is the main general medical device directive (European Union, 1993);

- Directive 98/79, which covers in vitro diagnostics (European Union, 1998).

In 2017 the new European Union Medical Device Regulation (MDR) was approved by the European Parliament, which embodies significant changes to the current EU regulation and repeals Council Directives 90/385/EEC (European Union, 1990), 93/42/EEC (European Union, 1993), 98/79/EC (European Union, 1998) and Commission Decision 2010/227/EU (European Union, 2017b). The main documents of the new MDR are:

- Regulation(EU) 2017/745 (European Union, 2017a);

- Regulation(EU) 2017/746(European Union, 2017b);

- Regulation(EU) 2017/2185 (European Union, 2017c).

The European device regulation defines the conformity assessment processes which are carried out by the established "notified bodies", based on the fulfillment of the safety and effectiveness essential principles (general safety and performance requirements), the core elements and procedures that companies need to have in place. The "competent authorities" are the agencies that control clinical trials, designate and supervise the notified bodies, and oversee post marketing surveillance. The conformity assessment is supported by the International Organization for Standardization (ISO) and European standards and guidelines.

In Europe, there are three classes of medical devices, but four categories with different conformity assessment procedures (European Union, 2017a; Van Drongelen et al., 2015):

- Class I, self-regulation and registration in each member state where they are marketed;

- Class IIA, selective quality system review;

- Class IIB, quality system review and targeted review of the design dossier;

- Class III, full design dossier review.

Moreover, Europe has a directive regarding advanced therapy products (European Commission, 2007a), which covers tissue engineering, cell therapy and gene therapy products. The legislation covers both allogeneic and autologous products. The borderline products have to be classified as pharmaceutical or devices, because a product cannot be assessed under more than one directive.

As it can be seen, the basis of the US and European regulatory systems is the categorization of medical devices in risk classes. Higher risk devices are subject to more rigorous conformity assessment procedures. However, 
Europe has a strict set of rules to categorize the devices in their risk classes, while the USA follows a much more diffuse approach (Van Drongelen et al., 2015). Another difference between both regulatory systems is that the market authorization procedures in the USA are performed entirely by the governmental agency (FDA), while in Europe these are performed by Notified Bodies (NB), most of them private companies, designated and supervised by the governmental competent authorities.

Gollaher and Goodall (2011) pointed out that in the period between 2004 and 2010 there was a clear trend that the more complex, and often cutting edge, a product was, the more likely it was to be approved first in Europe versus the United States, with almost equivalent ratio of recalled medical devices for safety issues in both regions. However, Basu and Hassenplug (2012) argued that a review of the data, using appropriate end-points, suggests instead that the USA process for approving innovative, high risk medical devices takes the same amount of time as it does in the four largest European markets (Germany, France, Italy and United Kingdom). In fact, cases where products on the market led to major problems for patients occurred in the USA and the EU showing that both systems are not perfect and the level of safety provided is not different (Kramer et al., 2012). The most important conclusion of these studies are that, despite the fact that strong regulations exist, the risk of putting into the market insufficiently tested devices still remains, and that the effective review process is still an issue of academicians, industry, government and social concern (Zuckerman et al., 2011).

In 2011 the Center for Devices and Radiological Health announced the Medical Device Innovation Initiative, which will allow companies to achieve regulatory approval of cutting-edge medical devices quicker than ever before (Center for Devices and Radiological Health, 2011), encouraging innovation of novel, important, safe and effective medical devices. To be chosen for Priority Review, the device had to be radically different from any marketed medical device in the United States in its principal technology or way of use (Food and Drug Administration, 2013). The device must also be designed to either significantly improve upon currently available treatment or diagnostics for life-threatening or irreversibly debilitating diseases or conditions; to treat or diagnose a life-threatening or irreversibly debilitating disease or condition for which no approved or cleared alternative treatment or means of diagnosis exists; to address an unmet public health need as identified by the Council on Medical Device Innovation; or to address an issue relevant to national security.

As the national regulations for medical devices have been developed, work has also been undertaken on their international harmonization, firstly in the Global
Harmonization Task Force (GHTF) (Gagliardi, 2009) and nowadays in the International Medical Device Regulators Forum (IMDRF). Regional efforts for harmonization of Medical Device Regulatory Frameworks are also undertaken outside the European Union (Lamph, 2012), for example by the Asian Harmonization Working Party (Asian Harmonization Working Party, 2014) and in the Common Southern Market (Buenos Aires, 2000).

Harmonization reduces regulatory load and promotes industry compliance. Following international guidelines, many regulatory programs use international standards and guidelines as a basis of their national technical regulations (International Medical Device Regulators Forum, 2014). The recommendations of the IMDRF have been taken into consideration by the International Organization for Standardization (ISO) for the development of standards in the field of medical devices, including the standard about the recognized essential principles of safety and performance of medical devices (International Organization for Standardization, 2016b) and the good clinical practice for investigation of medical device for human subjects (International Organization for Standardization, 2011).

However, the implementation of harmonized regulations depends on the national regulatory capabilities. Therefore, these capacities have to be strengthened for allowing the incorporation and deployment of common standards in all countries (Pombo et al., 2016).

\section{Innovation in the Medical Devices Sector}

The Oslo Manual is the main international source for the classification of innovations and as a guide for the collection and use of data on innovation activities in the industry. This document classifies innovations in: innovation of products and services, innovations in processes, innovations in marketing methods and organizational innovations (Organization for Economic Cooperation and Development, 2005). This document deals with innovations in medical technologies, which have their particularities.

A medical technology for being considered an innovation has to demonstrate a therapeutic superiority in a randomized clinical trial, where the control group is treated according to the current best practice and the primary endpoint is clinically relevant (Adami et al., 2012). However, Ciani et al. (2016) consider that this definition may be not adequate to characterize innovations in the medical devices field, because most of the time innovative medical devices cannot undergo blind randomized clinical trials for ethical reasons. Nowadays, while some experts claim for applying randomized clinical trials as the gold standard for assessing medical devices (Neugebauer et al., 2017), others argue in favor of real 
practice based clinical evidence (Tarricone et al., 2016) and the regulatory use of the "big data" (Erdman et al., 2013), which include information from electronic health records and expanded patient registries.

Ciani et al. (2016) classified the existing definitions of medical device innovations according to three elements: the source of innovation; the degree of discontinuity introduced and the consequences of innovation (Figure 3).

Using the technology-push view, innovation is an entrepreneurial process entailing the series of steps taken from the idea to invention, to development, to commercialization. From a demand-pull perspective, innovation is a way to meet specific clinical needs not addressed yet. However, both approaches belong to the linear models of innovation already overcome by mixed or interactive models (coupling models), stage models, network and open innovation models (Davey et al., 2011).

The introduction of innovative medical devices to the health service is slower than for other consumer products due to the barriers to innovation (Bergsland et al., 2014). However, open innovation models allow medical devices companies to manage the ideas of multiple stakeholders and made lower the existing barriers for reaching the market more quickly (Davey et al., 2011). Successful cases exist of collaboration between academia, health institutions, industry and regulatory agencies for developing innovative medical devices (Bonutti et al., 2008; Courvoisier, 2016; Markiewicz et al., 2017), overcoming the barriers to innovation in medical products by coordinated efforts among critical stakeholders.

The relevance of the relationships between medical devices developers and leading users/clinicians is stressed in the literature (Camp et al., 2015; Chatterji et al., 2008; Gelberman et al., 2010; Smieliauskas, 2016; Taylor, 2013; Van Haute, 2011). These relationships can be strengthened by means of direct demands and offers, but also by the participation in academic activities such as conferences, meetings and so on. These activities are also important for the optimization of the learning curve for a new technology. However, financial relationships between physicians and medical device manufacturers is a subject of considerable controversy due to ethical considerations. While some experts worry about the idea that these relationships will influence the physicians' decisions about which devices to use and how to document patients' outcomes compromising patients' welfare, others sustain that they are essential to device innovation.

Based on their intensity, innovation in medical devices can be classified as incremental or as breakthrough, but with many intermediary cases between those extreme categories. In the third approach, when medical devices innovation is classified by its beneficial impacts, not only the direct clinically meaningful benefit has to be addressed, but also the additional consequences at the level of user/consumer, single organizations or the whole health system, in terms of service quality, costs and ethical aspects (Vijayavenkataraman et al., 2016).

\section{Effects of Regulations on Innovation in Medical Devices}

Regulatory issues impact on the whole cycle of the innovation (Figure 4). They have to be taken into account in the early steps of the medical device design and development, during pre-clinical and clinical evaluation, product regulatory evaluation, manufacturing and post-marketing surveillance. For this reason, the relationship between medical devices developers and the national regulations agencies is critical for the innovation and competitiveness in this sector (Lind, 2017).

Because the regulatory agencies approval is required before the new product can go to the market, governmental policies and actions in this field constitute the external framework for medical products innovations (Figure 5). However, as medical devices become increasingly complex, the responsibility of assuring the safety and effectiveness of devices falls not only on the national

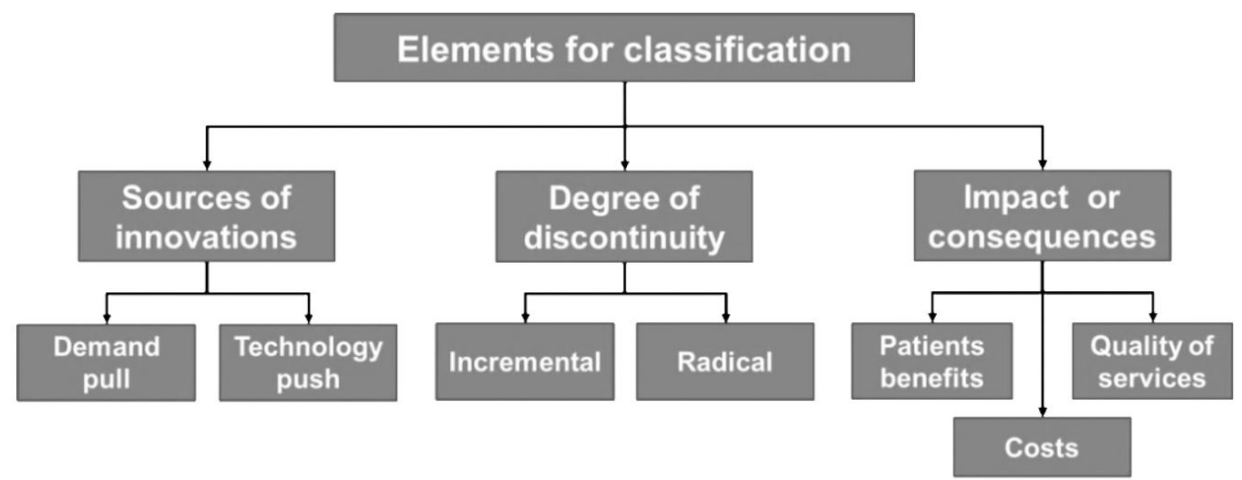

Figure 3. Elements for classification of innovations in the medical devices field. 


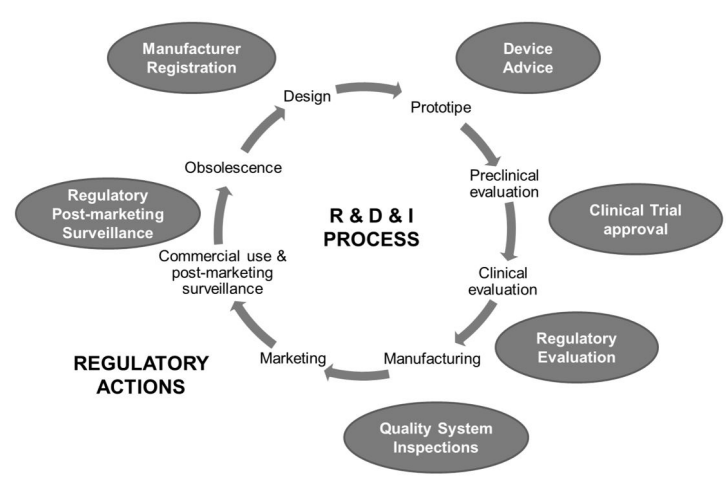

Figure 4. Links between research, development and innovation (R \& D \& I) process and regulatory agencies actions.

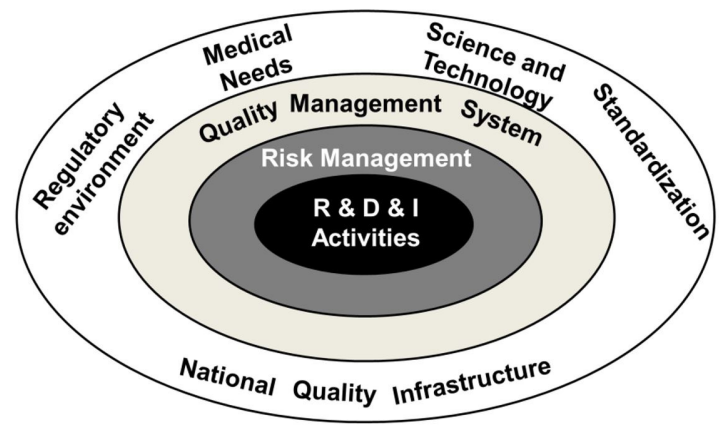

Figure 5. External and internal framework for medical device innovation.

regulatory agencies but also on industry, practitioners, and patients. Indeed, developers have to worry about regulatory issues even at the earlier design and developing stages of the innovative medical device.

The internal framework for medical device research, development and innovation (R\&D\&I) activities is the Quality Management System of the manufacturer, which should include an appropriate Risk Management (Figure 5).

Quality and risk management approaches through the whole life cycle of the medical products have to be integrated to demonstrate compliance with the "Essential Principles of Safety and Performance of Medical Devices" (Global Harmonization Task Force, 2012). Risk management involves the identification and description of hazards associated with medical devices and their accessories; risk analysis, evaluation and control, and monitoring of the effectiveness of that control. The ISO 14971:2007 international standard provides a process to address risk management related to medical devices, which is included in the harmonized legal requirements in most countries (International Medical Device Regulators Forum, 2015).

Controlling the risks is a central requirement of the design controls of the FDA Quality Systems Regulation
(Food and Drug Administration, 1997) and the ISO 13485 quality system standard (International Organization for Standardization, 2016a). Both documents include requirements related to the methods, facilities and controls for designing, manufacturing, packaging, labeling, storing, installing, and servicing of medical devices intended for human use. Also, device manufactures are required to collect post-market information, including clinical data, as part of their risk management system.

Risks should be reduced or eliminated as far as possible during the lifetime of the device and, if overall residual risk persists, there should be a favorable benefit/risk ratio. In selecting the most appropriate solutions to reduce risks, the manufacturer must apply the control options in the following order (European Union, 2017a):

1. inherently safe design and construction;

2. protection measures where appropriate, including alarms if necessary, in relation to risks that cannot be eliminated;

3. to inform users of the residual risks due to any shortcomings of the protection measures adopted.

Stern (2017) considers that the regulatory process strongly affects market entry patterns of the small firms and that they are less likely to be pioneers in new devices because of the relatively higher costs of doing so for more financially constrained firms. He argues that pioneer entrants in new device categories spend 7.2 months longer in the approval process than the followers in that category and that the costs of this delay heighten in 7 percent the total $R \& D$ costs associated with getting a new high-risk medical device into the market. The established regulatory precedents smooth the way for subsequent entrants. The knowledge related to regulatory and marketing strategies contributes to the successful results for medical devices entrepreneurs (Chatterji, 2009).

Newer innovative medical devices are characterized by a large product heterogeneity and significant uncertainty about the regulatory process itself. The "regulatory uncertainty", regarding if and when a national regulatory agency will approve an innovative device, brings certain discouragement in medical device innovation (Fleming, 2015).

Stern (2017) divides the "regulatory uncertainty" into two components (Figure 6): "technological uncertainty" and "content and format uncertainty". To reduce the uncertainty, early contacts between developers and regulators should stimulate the identification and solution of key scientific and regulatory issues related to the innovative medical device during the early stages of product development and regulatory approval. Face-to-face meeting between developers and regulators could help to improve the study of protocols for testing 
- A lack of technological or scientific understanding of a specific type of

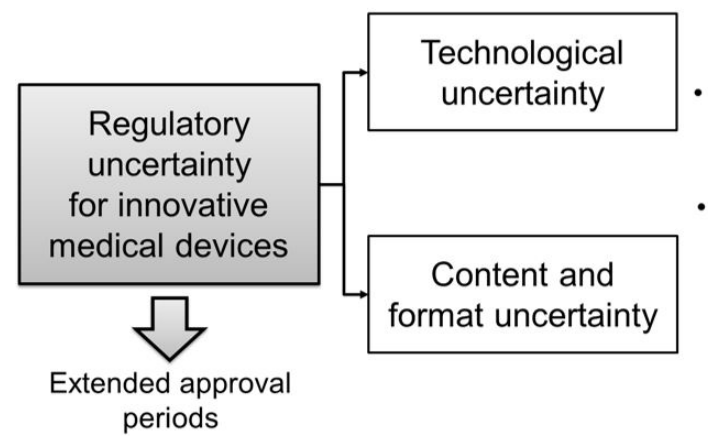
product and its use in the human body.

- Lack ok knowledge about the data required to be convinced of a product's safety and effectiveness.

- Absence of clear guidelines for evaluating a new product, leading to uncertainty as to how to present (on the part of the applicant firm) and assess (on the part of the regulator) the results of tests.

Figure 6. Elements of "regulatory uncertainty" that influences in the approval period for new type innovative products.

devices. On the other hand, it is idealistic to expect the regulatory experts to have all the necessary expertise and experience for reviewing all medical devices of emerging scientific fields and pioneering technologies (Camp et al., 2015).

Regulations have to be clear and transparent, but they also have to be flexible enough, responding to the medical device innovation and global market needs. In this way, the US FDA Center for Devices and Radiological Health undertake the Medical Device Innovation Initiative with the aim of helping to accelerate and reduce the cost of development and regulatory evaluation of innovative medical devices safely and based on comprehensive science. The actions included are a priority review program for pioneering medical devices (the Innovation Pathway) and the streamlining of the "De Novo" pathway (Food and Drug Administration, 2013).

However, more advanced regulatory research has to be done in critical aspects, such as identifying appropriate clinical endpoints and key scientific questions. In this way, collaboration with external partners (other government agencies, academia, industry, patients' organizations and professional associations) can provide valuable information for more effective and efficient regulatory review processes, reducing medical device innovation costs and helping to faster delivery of safe new products to patients (Krucoff et al., 2012).

FDA developed a Humanitarian Device Exemption program for products aimed for rare disease (Mokhtarzadeh et al., 2016). This program takes into account that for rare disease populations randomized clinical trials are impracticable. However, devices approved by this exemption are subjected to some restrictions such as the need for approval from relevant institutional review boards before use. Furthermore, in 2015 FDA issued a draft guidance document on benefit-risk determinations for investigational device exemptions (Food and Drug Administration, 2016b) and other regulations to streamline the approval of devices intended for unmet medical needs for life threatening or irreversibly debilitating diseases or conditions and early feasibility studies designed to gain quick insights into an innovative technology during the development process before starting a larger clinical trial (Food and Drug Administration, 2016a).

Barriers to innovation in medical products have to be overcome by coordinated efforts among critical stakeholders, including patient groups, medical societies, device companies, clinical research organizations, and government organizations committed to working together to improve patient health and quality of life, and the healthcare service quality at reasonable costs.

\section{Analysis of Innovative Medical Technologies Cases}

\section{Nanomaterials}

Medical innovations using the advances in nanotechnology are confusing the existing product classification scheme (Paradise et al., 2008), which is a very important regulatory matter; because depending on it is the approval process the product will follow. In reply, regulatory agencies continue utilizing the existing regulatory pathways to review medical products containing nanomaterials, but they are beginning to consider new issues related to nanotechnology products and applications. Furthermore, many products containing nanomaterials fall into the so called "combination products" or products in "borderline cases" involving medicinal products, human tissues and cells, biocidal products or food products, that are classified according to their "primary mode of action".

The application of the FDA procedure of "substantial equivalence" of nanotechnology-based devices to nonnanotechnology-based predicate devices is a controversial issue, because both use a different fundamental scientific technology. However, such analysis has to be done case 
by case because there may be devices, in which the included nanotechnology element does not affect their operation, then "no different fundamental scientific technology" may be claimed, and the manufacturer must demonstrate that the new device is substantially equivalent to a legally marketed device (Abbott Curry and Goos, 2012).

In the European Union the report of the Working Group on New and Emerging Technologies in Medical Devices concluded that existing legislation is adequate to deal with nanotechnology-based medical devices (European Commission, 2007b). However, devices presenting risks associated with nanomaterials have to be subjected to a systematic pre-market review (European Commission, 2008).

It is generally accepted that medical devices with nanocomponents require specific techniques for characterization and biocompatibility testing, because they have unique properties associated with their nanocomponents such as aggregation, agglomeration, immunogenicity, or toxicity (Kunzmann et al., 2011; Rivera et al., 2010). Considerations have to be taken of any additional toxicity issues that might be relevant to submicron particles, such as absorption, distribution, and accumulation into organs, potential metabolism and elimination. It is a generalized opinion that the nanomaterials themselves need to be evaluated instead of extracts as usually used when testing biomaterials or medical devices. For these reasons, the validity of individual assessment tests commonly used for classical biomaterial are being explored, and specific ISO guidance for biocompatibility assessment of devices with nanomaterials was recently published (International Organization for Standardization, 2017).

\section{Materials for tissue engineering and 3D-bioprinting}

In tissue engineering, biomaterials are used as "scaffolds" or "templates", which can mimic the native extracellular matrix and provide structural support for cell attachment and growth in the presence of physicochemical factors that stimulate new tissue formation, which can be then implanted into organism. In these circumstances the biomechanical and biophysical characteristics of the material are significant to the manner in which the new tissue is generated, but the first requirement of a tissue engineering template is to have specific biological activity for the target cells to be stimulated. As Williams $(2014,2015)$ argue, this is the main reason why biocompatibility has to be re-defined as a property of a system and not only of a material and new theories and biocompatibility tests have to be developed for biomaterials used in tissue engineering.

This paradigm shift has significant regulatory implications, as biomaterials start to exhibit mechanisms of action that involve metabolic functions (Chen et al., 2013). Then, the research question is how to evaluate the potential of the material to actively signal the target cells, and the classical ISO 10993 biological tests are not intended to do this.

3D-Bioprinting is a subset of tissue engineering as a tool for engineering complex tissues. This technology could help overcome the limitations of the current tissue engineering methods, including the problem of longer waiting times for treatment, especially with organ transplants (Vijayavenkataraman et al., 2016). While, academic and industrial research on innovative 3D medical devices are moving swiftly, the issues concerning ethics, policies, regulations and social acceptance are not addressed with the needed speed.

Since 3D-bioprinting is a complex field including the printing devices, drugs, cells and biomaterials, each of these governed by a different regulation in many countries; the clinical translation becomes very complicated (Bajaj et al., 2014; Zhang and Wang, 2017)

The unknown consequences of implanting an artificial construct or organ into the body make indispensable to conduct pre-clinical testing not only for the final bioprinted product, tissue construct or organ, but also for individual elements of the product separately, to assess their effects on the body, because after implantation it is impracticable to decide which element is provoking an inadequate response (Vijayavenkataraman et al., 2016).

Clinical testing following the in vivo pre-clinical successful evaluation is also necessary due to the difference in response between the animals and humans. Controlled clinical trials are ethically impracticable in this type of therapy, thus a global registry of pre-clinical and clinical testing of such implants, accessible for researchers, physicians and patients all over the world is the best approach.

\section{Concluding Remarks}

Based on the conducted review, the following conclusions may be drawn:

1. Strong medical devices regulations exist and are aimed at protecting patients and the whole society from unsafely products, and at promoting public health introducing innovative products into the market, which can be beneficial to patients. However, the risk of putting into the market insufficiently tested devices still remains, and the effective review 
process is still an issue of academicians, industry, government and social concern;

2. The cornerstone of the most developed regulatory systems in the world is the classification of the medical products into drugs, biologic or medical devices; however innovative combination products incorporate challenges to the existing product classification scheme. Furthermore, categorization of medical devices in risk classes is also stressed by the application of new technologies in medical devices design, such as nanotechnology, tissue engineering and 3D-printing. The responsibility of assuring the safety and effectiveness of devices falls, not only on the national regulatory agencies, but primarily on researchers, manufactures and physicians, even at the earlier stages of the innovation process;

3. Innovations in the field of medical devices have peculiarities that make difficult the conduction of randomized clinical trials. However, there is a clear understanding of the need for clinical evidence and clinical evaluation in proportion to the class of risk of the medical device, including the recording of clinical data during the post-marketing surveillance;

4. Open innovation models and early collaboration between medical device developers and regulatory agencies could contribute to break down the existing barriers to medical device innovation. However, in order to maintain the needed partnership with the medical devices developers, the regulatory agencies have to develop regulatory science according to the development of new technologies, maintaining the balance between high standards for quality, safety and effectiveness and the streamlining of the regulatory review process to encourage and facilitate the innovation process in medical devices. Collaborative regulatory research and device evaluation can help in improving regulatory pathways for medical devices of emerging scientific fields and pioneering technologies;

5. Newer innovative medical devices are characterized by a large product heterogeneity and significant uncertainty about the regulatory process itself. Emerging innovative products, such as nanobiomaterials, materials for tissue engineering and 3D-bioprinting, need the development of more appropriate assay methods and streamline regulatory and scientific device evaluation to encourage innovation and ensure more expedite delivery of novel, safe and effective innovative medical devices to patients;
6. Academic and industrial research and commercialization of innovative medical devices are moving at a higher speed than the issues concerning assay methods, clinical evaluation, ethics and regulations. Collaboration among all the stakeholders can contribute to overcome the existing problems in medical device innovation.

\section{Acknowledgements}

This work was conducted in the framework of the Academic Network for Research in Quality, and supported by the Biomaterials Center at the Havana University, Cuba, and the Metropolitan Technological Institute of Medellin, Colombia.

\section{References}

Abbott Curry J, Goos S. Medical devices. In: Duvall MN. FDA regulation of nanotechnology. Washington: Food and Drug Administration; 2012. Chap. 8, p. 94-106.

Adami S, Ciampalini S, Dell'Aera M, Di Turi R, Ferrarese A, Messori A, Palozzo A, Polidori P, Romero M, Venturini F. Defining innovations of therapeutic interventions: a position paper by the Italian Society of Hospital Pharmacists. Int J Clin Pharm. 2012; 34(2):259-62. http://dx.doi.org/10.1007/ s11096-012-9618-2. PMid:22382884.

Amato SF, Ezzell RM Jr. Regulatory affairs for biomaterials and mediunifiecal devices. Boston: Woodhead Publishing; 2014.

Asian Harmonization Working Party - AHWP. Playbook for implementation of medical device regulatory frameworks. AHWPTC/OB/R001:2014. Hong Kong: Asian Harmonization Working Party; 2014.

Bajaj P, Schweller RM, Khademhosseini A, West JL, Bashir R. 3D biofabrication strategies for tissue engineering and regenerative medicine. Annu Rev Biomed Eng. 2014; 16(1):2476. http://dx.doi.org/10.1146/annurev-bioeng-071813-105155. PMid:24905875.

Basu S, Hassenplug JC. Patient access to medical devices - a comparison of U.S. and european review processes. N Engl J Med. 2012; 367(6):485-8. http://dx.doi.org/10.1056/ NEJMp1204170. PMid:22852882.

Bergsland J, Elle OJ, Fosse E. Barriers to medical device innovation. Med Devices (Auckl). 2014; 13(7):205-9. http:// dx.doi.org/10.2147/MDER.S43369. PMid:24966699.

Bonutti PM, Seyler TM, Bianco PD, Ulrich SD, Mont MA. Inventing in orthopaedics: from idea to marketed device. J Bone Joint Surg Am. 2008; 90(6):1385-92. http://dx.doi. org/10.2106/JBJS.G.01407. PMid:18519334.

Buenos Aires. Ministerio de Justicia y Derechos Humanos. Mercosur/GMC/Res. N 40/00 Reglamento Técnico MERCOSUR de Registro de Productos Médicos (Derogacion de la Resolucion GMC No 37/96) [Internet]. Buenos Aires: Grupo Mercado Común; 2000 [cited 2018 Mar 9]. Available from: http://servicios.infoleg. gob.ar/infolegInternet/anexos/60000-64999/63755/norma.htm 
Camp MW, Gross AE, McKneally MF. Patient views on financial relationships between surgeons and surgical device manufacturers. Can J Surg. 2015; 58(5):323-9. http://dx.doi. org/10.1503/cjs.000815. PMid:26384147.

Center for Devices and Radiological Health - CDRH. Innovation initiative. Silver Spring: Center for Devices and Radiological Health, U.S. Food and Drug Administration; 2011.

Chatterji AK, Fabrizio KR, Mitchell W, Schulman KA. Physician-industry cooperation in the medical device industry. Health Aff (Millwood). 2008; 27(6):532-43.

Chatterji AK. Spawned with a silver spoon? Entrepreneurial performance and innovation in the medical device industry. Strateg Manage J. 2009; 30(2):185-206. http://dx.doi. org/10.1002/smj. 729 .

Chen L, Wang C, Xi T. Regulation challenge of tissue engineering and regenerative medicine in China. Burns Trauma. 2013; 1(2):56-62. http://dx.doi.org/10.4103/2321-3868.118927. PMid:27574626.

Ciani O, Armeni P, Boscolo PR, Cavazza M, Jommi C, Tarricone R. De innovatione: the concept of innovation for medical technologies and its implications for health care policy-making. Health Policy Technol. 2016; 5(1):47-64. http://dx.doi.org/10.1016/j.hlpt.2015.10.005.

Courvoisier A. The future of academic innovation in the field of medical devices: is innovation still possible in orthopedics? Expert Rev Med Devices. 2016; 13(9):807-13. http://dx.doi.or g/10.1080/17434440.2016.1219944. PMid:27484288.

Curfman GD, Redberg RF. Medical devices — balancing regulation and innovation. N Engl J Med. 2011; 365(11):975-7. http://dx.doi.org/10.1056/NEJMp1109094. PMid:21830959.

Davey SM, Brennan M, Meenan BJ, McAdam R. Innovation in the medical device sector: an open business model approach for high-tech small firms. Technol Anal Strateg Manage. 2011; 23(8):807-24. http://dx.doi.org/10.1080/09537325.2011.604152.

Erdman AG, Keefe DF, Schiestl R. Grand challenge: applying regulatory science and big data to improve medical device innovation. IEEE Trans Biomed Eng. 2013; 60(3):700-6. http:// dx.doi.org/10.1109/TBME.2013.2244600. PMid:23380845.

European Commission. Working Group on new and emerging technologies in medical devices. Report on nanotechnology to the medical devices expert group, Findings and recommendations [Internet]. Brussels: European Commission; 2007a [cited 2018 Feb 21]. Available from: http://ec.europa.eu/enterprise/ newsroom/cf/_getdocument.cfm?doc_id $=4865$

European Commission. Regulation (EC) No 1394/2007 of the European Parliament and of the Council of 13 November 2007 on advanced therapy medicinal products and amending Directive 2001/83/EC. and Regulation (EC) No 726/2004. Official Journal of the European Union [Internet], Brussels, 2007b [cited 2018 Feb 21]. Available from: https://eur-lex. europa.eu/LexUriServ/LexUriServ.do?uri=OJ:L:2007:324:0 121:0137:en:PDF

European Commission. Regulatory aspects of nanomaterials [Internet]. Brussels: European Commission; 2008 [cited 2018 Feb 21]. Available from: http://ec.europa.eu/nanotechnology/ pdf/comm_2008_0366_en.pdf. Communication from the
Commission to the European Parliament, the Council and the European Economic and Social Committee.

European Union. Council directive 90/385/EEC of 20 June 1990 on the approximation of the laws of the member states relating to active implantable medical devices. Official Journal of the European Union [Internet], Brussels, 1990 [cited 2018 Feb 21]. Available from: http://eur-lex.europa.eu/LexUriServ/ LexUriServ.do?uri=CONSLEG:1990L0385:20071011:en:PDF

European Union. Council directive 93/42/EEC of 14 June 1993 concerning medical device. Official Journal of the European Union [Internet], Brussels, 1993 [cited 2018 Feb 21]. Available from: http://eur-lex.europa.eu/LexUriServ/LexUriServ.do?ur $\mathrm{i}=$ CONSLEG:1993L0042:20071011:en:PDF

European Union. Council directive Directive 98/79/EC of 27 October 1998 on in vitro diagnostic medical devices. Official Journal of the European Union [Internet], Brussels, 1998 [cited $2018 \mathrm{Feb} 21]$. Available from: https://eur-lex.europa.eu/legalcontent/en/TXT/?uri=CELEX:31998L0079

European Union. Regulation (EU) 2017/745 of the European Parliament and of the Council of 5 April 2017 on medical devices, amending Directive 2001/83/EC, Regulation (EC) No $178 / 2002$ and Regulation (EC) No 1223/2009 and repealing Council Directives 90/385/EEC and 93/42/EEC. Official Journal of the European Union [Internet], Brussels, 2017a [cited 2018 Feb 21]. Available from: http://eur-lex.europa.eu/legal-content/ EN/TXT/? uri=CELEX\%3A32017R0745

European Union. Regulation (EU) 2017/746 of the European Parliament and of the Council of 5 April 2017 on in vitro diagnostic medical devices and repealing Directive 98/79/EC and Commission Decision 2010/227/EU. Official Journal of the European Union [Internet], Brussels, 2017b [cited 2018 Feb 21]. Available from: https://eur-lex.europa.eu/legal-content/ EN/TXT/?uri=CELEX\%3A32017R0746

European Union. Regulation (EU) 2017/2185 of 23 November 2017 on the list of codes and corresponding types of devices for the purpose of specifying the scope of the designation as notified bodies in the field of medical devices under Regulation (EU) 2017/745 of the European Parliament and of the Council and in vitro diagnostic medical devices under Regulation (EU) 2017/746 of the European Parliament and of the Council. Official Journal of the European Union [Internet], Brussels, 2017c [cited 2018 Feb 21]. Available from: https://eur-lex. europa.eu/eli/reg_impl/2017/2185/oj

Fleming JJ. The decline of venture capital investment in earlystage life sciences poses a challenge to continued innovation. Health Aff (Millwood). 2015; 34(2):271-6. http://dx.doi. org/10.1377/hlthaff.2014.1051. PMid:25646107.

Food and Drug Administration - FDA. 21 CFR Part 820 FDA Quality System Regulation. Silver Springs: FDA; 1997.

Food and Drug Administration - FDA. Priority review of pre-market submissions for devices: guidance for industry and food and drug administration staff [Internet]. Silver Springs: FDA; 2013 [cited 2018 Feb 21]. Available from: http://www. fda.gov/MedicalDevices/DeviceRegulationandGuidance/ GuidanceDocuments/ucm089643.htm

Food and Drug Administration - FDA. Expedited access for premarket approval and de novo medical devices intended 
for unmet medical need for life threatening or irreversibly debilitating diseases or conditions [Internet]. USA: FDA; 2016a [cited 2018 Feb 21]. Available from: http:/www.fda.gov/ downloads/MedicalDevices/DeviceRegulationandGuidance/ GuidanceDocuments/UCM393978.pdf

Food and Drug Administration - FDA. Factors to consider when making benefit -risk determinations for medical device investigational device exemptions [Internet]. USA: FDA; 2016 b [cited $2018 \mathrm{Feb} 21]$. Available from: http://www.fda.gov/ ucm/groups/fdagov-public/@fdagov-meddevgen/documents/ document/ucm451440.pdf

Gagliardi J. The global harmonization task force: what you need to know. Biomed Instrum Technol. 2009; 43(5):403-5. http://dx.doi.org/10.2345/0899-8205-43.5.403. PMid:19842776.

Gelberman RH, Samson D, Mirza SK, Callaghan JJ, Pellegrini VD Jr. Orthopaedic surgeons and the medical device industry: the threat to scientific integrity and the public trust. J Bone Joint Surg Am. 2010; 92(3):765-77. http://dx.doi.org/10.2106/ JBJS.I.01164. PMid:20194337.

Global Harmonization Task Force-GHTF. Essential principles of safety and performance of medical devices. USA: GHTF; 2012. GHTF/SG1/N68:2012.

Gollaher DL, Goodall S. Competitiveness and regulation: the FDA and the future of America's biomedical industry. La Jolla: California Health Care Institute; 2011.

Ho M, Saha A, McCleary KK, Levitan B, Christopher S, Zandlo $\mathrm{K}$, Braithwaite RS, Hauber AB. A framework for incorporating patient preferences regarding benefits and risks into regulatory assessment of medical technologies. Value Health. 2016; 19(6):746-50. http://dx.doi.org/10.1016/j.jval.2016.02.019. PMid:27712701.

Howard JJ. Balancing innovation and medical device regulation: the case of modern metal-on-metal hip replacements. Med Devices (Auckl). 2016; 9:267-75. http://dx.doi.org/10.2147/ MDER.S113067. PMid:27563260.

International Medical Device Regulators Forum - IMDRF. List of international standards recognized by IMDRF management committee members. USA: IMDRF Standards Working Group; 2014. IMDRF/Standards/N15FINAL:2014. Final Report.

International Medical Device Regulators Forum - IMDRF. Statement regarding use of ISO 14971:2007 "Medical devices - Application of risk management to medical devices". USA: IMDRF Standards Working Group; 2015. IMDRF/MC/N34 FINAL:2015. Final Report.

International Organization for Standardization - ISO. ISO 14155:2011 Clinical investigation of medical devices for human subjects - Good clinical practice. Geneva: ISO; 2011.

International Organization for Standardization - ISO. ISO 13485 Medical devices - Quality management systems -Requirements for regulatory purposes. Geneva: ISO; 2016a.

International Organization for Standardization - ISO. ISO 16142:2016 Medical Devices - Recognized Essential Principles of Safety and Performance of Medical Devices - Part 1: General Essential Principles and Additional Specific Essential Principles for all non-IVD Medical Devices and Guidance on the Selection of Standards. Geneva: ISO; 2016b.
International Organization for Standardization - ISO. ISO/TR 10993-22 Biological evaluation of medical devices - Part 22: Guidance on nanomaterials. Geneva: ISO; 2017. Technical report.

Kramer D, Xu S, Kesselheim AS. Regulation of medical devices in the United States and European Union. N Engl J Med. 2012; 366(9):848-55. http://dx.doi.org/10.1056/NEJMhle1113918. PMid:22332952.

Krouse JH. Balancing evidence, innovation, and regulation. Otolaryngol Head Neck Surg. 2015; 152(4):579-80. http:// dx.doi.org/10.1177/0194599815572798. PMid:25833920.

Krucoff M, Brindis RG, Hodgson PK, Mack MJ, Holmes DR Jr. Medical device innovation: prospective solutions for an ecosystem in crisis. Adding a professional society perspective. JACC Cardiovasc Interv. 2012; 5(7):790-6. http://dx.doi. org/10.1016/j.jcin.2012.03.023. PMid:22814785.

Kunzmann A, Andersson B, Thurnherr T, Krug H, Scheynius A, Fadeel B. Toxicology of engineered nanomaterials: focus on biocompatibility, biodistribution and biodegradation. Biochim Biophys Acta. 2011; 1810(3):361-73. http://dx.doi. org/10.1016/j.bbagen.2010.04.007. PMid:20435096.

Lamph S. Regulation of medical devices outside the European Union. J R Soc Med. 2012; 105(S1):S12-21. http://dx.doi. org/10.1258/jrsm.2012.120037.

Lind KD. Implantable devices: regulatory framework and reform options. Vol. 130. Washington: AARP Public Policy Institute; 2017 [cited 2018 Feb 21]. Available from: https:// www.aarp.org/content/dam/aarp/ppi/2017/08/implantabledevices-regulatory-framework-and-reform-options.pdf

Markiewicz K, van Til J, IJzerman M. Early assessment of medical devices in development for company decision making: an exploration of best practices. J Commer Biotechnol. 2017; 23(2):15-30. http://dx.doi.org/10.5912/jcb780.

Mokhtarzadeh M, Eydelman M, Chen E. Challenges and opportunities when developing devices for rare disease populations. Expert Opin Orphan Drugs. 2016; 4(5):457-9. http://dx.doi.org/10.1517/21678707.2016.1166948.

Neugebauer EAM, Rath A, Antoine SL, Eikermann M, Seidel D, Koenen C, Jacobs E, Pieper D, Laville M, Pitel S, Martinho C, Djurisic S, Demotes-Mainard J, Kubiak C, Bertele V, Jakobsen JC, Garattini S, Gluud C. Specific barriers to the conduct of randomised clinical trials on medical devices. Trials. 2017; 18(1):427. http://dx.doi.org/10.1186/s13063-017-2168-0. PMid:28903769.

Organization for Economic Cooperation and Development OECD. Guidelines for collecting and interpreting innovation data - The Oslo Manual, 3rd ed. Paris: OECD; 2005.

Pane J, Coloma PM, Verhamme KM, Sturkenboom MC, Rebollo I. Evaluating the safety profile of non-active implantable medical devices compared with medicines. Drug Saf. 2017; 40(1):37-47. http://dx.doi.org/10.1007/s40264-016-0474-1. PMid:27928726.

Paradise J, Diliberto GM, Tisdale AW, Kokkoli E. Exploring emerging nanobiotechnology drugs and medical devices. Food Drug Law J. 2008; 407(2):417-20. PMid:18561467.

Pombo ML, Porrás A, Saidon PC, Cascio SM. Regulatory convergence and harmonization: barriers to effective use and 
adoption of common standards. Rev Panam Salud Publica. 2016; 39(5):217-25. PMid:27706409.

Rivera GP, Oberdorster G, Elder A, Puntes V, Parak WJ. Correlating physico-chemical with toxicological properties of nanoparticles: the present and the future. ACS Nano. 2010; 4(10):5527-31. http://dx.doi.org/10.1021/nn1025687. PMid:20973573.

Smieliauskas F. Conflicts of interest in medical technology markets: evidence from orthopedic surgery. Health Econ. 2016; 25(6):723-39. http://dx.doi.org/10.1002/hec.3177. PMid:25845858.

Stern AD. Innovation under regulatory uncertainty: evidence from medical technology. J Public Econ. 2017; 145:181-200. http://dx.doi.org/10.1016/j.jpubeco.2016.11.010. PMid:28652646.

Tarricone R, Boscolo PR, Armeni P. What type of clinical evidence is needed to assess medical devices? Eur Respir Rev. 2016; 25(141):259-65. http://dx.doi.org/10.1183/16000617.00162016. PMid:27581825.

Taylor PL. Innovation incentives or corrupt conflicts of interest? Moving beyond Jekyll and Hyde in regulating biomedical academic-industry relationships. Yale J Health Policy Law Ethics. 2013; 13(1):135-97. PMid:23815042.

Van Drongelen A, Hessels J, Geertsma R. Comparison of market authorization systems of medical devices in USA and Europe. Bilthoven: National Institute for Public Health and the Environment; 2015.

Van Haute A. Managing perceived conflicts of interest while ensuring the continued innovation of medical technology. J Vasc
Surg. 2011; 54(3 Suppl):31S-3S. http://dx.doi.org/10.1016/j. jvs.2011.05.108. PMid:21872113.

Van Norman GA. Drugs, devices, and the FDA: Part 2. An overview of approval processes: FDA approval of medical devices. JACC Basic Transl Sci. 2016; 1(4):277-87. PMid:30167516.

Vijayavenkataraman S, Lu WF, Fuh JY. 3D bioprinting an Ethical, Legal and Social Aspects (ELSA) framework. Bioprinting. 2016; 1-2:11-21. http://dx.doi.org/10.1016/j. bprint.2016.08.001.

Williams DF. Regulatory biocompatibility requirements for biomaterials used in regenerative medicine. J Mater Sci Mater Med. 2015; 26(2):89-90. http://dx.doi.org/10.1007/s10856015-5421-7. PMid:25649511.

Williams DF. There is no such thing as a biocompatible material. Biomaterials. 2014; 35(38):10009-14. http://dx.doi org/10.1016/j.biomaterials.2014.08.035. PMid:25263686.

Wizemann T. Public health effectiveness of the FDA 510(k) clearance process: balancing patient safety and innovation. Washington: The National Academies Press; 2010. Workshop report.

Zhang Z, Wang XJ. Current progresses of 3D bioprinting based tissue engineering. Quant Biol. 2017; 5(2):136-42. http://dx.doi. org/10.1007/s40484-017-0103-8.

Zuckerman D, Brown P, Nissen S. Medical device recalls and the FDA approval process. Arch Intern Med. 2011; 171(11):1006-11. http://dx.doi.org/10.1001/archinternmed.2011.30. PMid:21321283. 